\title{
Antidiarrhoeal potentials of methanol bark extract of Hymenocardia Acida Tul (Euphorbiaceae) in laboratory animals
}

\author{
Abba Musab Usman', Nuhu Muhammad Danjuma², Jamilu Ya'u², Muslim Muhammad Ahmad', \\ Zakariyya Alhassan², Yusuf Muhammad Abubakar ${ }^{1}$ and Mubarak Hussaini Ahmad ${ }^{2 *}$ (1)
}

\begin{abstract}
Background: The plant Hymenocardia acida (Euphorbiaceae) is utilized as herbal preparation against diarrhoea, dysentery and other diseases. We aimed to determine the antidiarrhoeal potentials of Hymenocardia acida (MEHA) stem bark in vivo and in vitro. Preliminary phytochemical contents, as well as the acute toxicity effect of the extract, were investigated based on standard experimental methods. The antidiarrhoeal properties of the MEHA at 150, 300 and $600 \mathrm{mg} / \mathrm{kg}$ were studied against diarrhoea induced by castor oil, intestinal fluid accumulation, as well as intestinal movement tests using distilled water $(10 \mathrm{ml} / \mathrm{kg})$ and loperamide/atropine sulphate as the control groups. Besides, the in vitro effects of the extract $\left(8 \times 10^{-2}-640 \times 10^{-2} \mathrm{mg} / \mathrm{ml}\right)$ on the rabbit jejunum and guinea-pig ileum were evaluated.
\end{abstract}

Results: Phytochemical screening showed alkaloids, glycoside, saponins, tannins, triterpenes, flavonoids and steroids in the MEHA. The median lethal dose $\left(\mathrm{LD}_{50}\right)$ of the MEHA after oral administration was approximately greater than $2000 \mathrm{mg} / \mathrm{kg}$. The MEHA declined the diarrhoea onset and remarkably decreased the number of watery stools in the group that received 300 and $600 \mathrm{mg} / \mathrm{kg}$. It also elicited a remarkable and non-dose-dependent reduction in the intestinal fluid volume. At $1000 \mathrm{mg} / \mathrm{kg}$, the MEHA significantly inhibited the charcoal movement. In addition, the MEHA $\left(8 \times 10^{-2}-640 \times 10^{-2} \mathrm{mg} / \mathrm{ml}\right)$ elicited a remarkable decrease in the contractility of the rabbit jejunum over time and relaxed the guinea pig ileum. Besides, it showed concentration-dependent attenuation of the acetylcholine and histamine-induced contraction.

Conclusion: The extract under investigation revealed promising antidiarrhoeal properties that justified its traditional claim for use against diarrhoea.

Keywords: Hymenocardia acida, Antidiarrhoeal properties, Isolated tissues, Castor oil-induced diarrhoea, Gastrointestinal motility, Traditional medicine, Medicinal plant

\section{Background}

Diarrhoea is the removal of liquid faeces thrice or more per day (Kola-Mustapha et al. 2019). The disease affects the gastrointestinal tract (GIT) and increases intestinal motility and secretory activities and decreases

\footnotetext{
*Correspondence: mubarakhussainiahmad@gmail.com

2 Department of Pharmacology and Therapeutics, Ahmadu Bello

University, Zaria, Kaduna, Nigeria

Full list of author information is available at the end of the article
}

water and electrolytes' absorption (Paredes et al. 2016). Thus, it manifests with an enhanced frequency, the volume of watery faeces accompanied by dehydration and loss of fluid and electrolytes (Emudainohwo et al. 2015). The pathophysiological process of diarrhoea includes increased intestinal osmolarity, excessive secretion of fluid and electrolytes, intestinal hypermotility and a reduction in the absorptive processes and intestinal residence time (Paredes et al. 2016). 
Diarrhoea can be categorized based on duration, namely acute diarrhoea, persistent diarrhoea and chronic diarrhoea (Mekonnen et al. 2018). It occurs due to irregular intestinal absorptive and secretory activities of fluid and electrolytes caused by infectious agents, toxicants, diet, allergic substances and GIT disorders including inflammatory bowel syndrome, dysmotility and drugs (Ezeja et al. 2012; Mekonnen et al. 2018; Whyte and Jenkins 2012). There have been different programs at the global level to tackle the burden of diarrhoea, particularly in developing countries. However, the disease has posed a serious health threat in these countries (Ezeja et al. 2012).

Diarrhoea is among the reasons for many sickness and death among children in developing nations as a result of inadequate hygiene and sanitation habit (Kola-Mustapha et al. 2019). Even though the international communities have continued to put more effort to curtail the spread of diarrhoea, the diseases caused close to 7.1 million fatalities each year (Pandey et al. 2012). It is the next forefront reason of mortality in children less than five birthdays after respiratory tract infections. Diarrhoea kills children more than the total deaths resulted from measles, malaria and acquired immunodeficiency syndrome (AIDS) (Kola-Mustapha et al. 2019; Tadesse et al. 2017). In 2012, diarrhoea caused more than $25 \%$ of all deaths in children less than five years globally (Yilgwan and Okolo 2012). Approximately $78 \%$ of all mortalities, especially in developing countries are caused by diarrhoea (Tadesse et al. 2017). In Nigeria, diarrhoea's prevalence is approximately $18.8 \%$, where it approximately caused 300,000 infants mortalities under 5 years (Yakubu et al. 2015).

Some synthetic therapeutic agents, including loperamide, diphenoxylate, diloxanide, racecadotril and atropine sulphate, have been utilized to curtail diarrhoea (Pandey et al. 2012; Sahoo et al. 2016). However, these therapeutic substances are associated with adverse effects, including vomiting, gastrointestinal discomfort, convulsion, headache as well as hallucination (Pandey et al. 2012; Yakubu et al. 2015). Besides, these conventional medicines at times are not affordable, and they are inaccessible to people in rural communities that lack basic health care facilities (Wansi et al. 2017). In addition, some antimicrobial agents are indicated to treat infectious diarrhoea. However, microbial resistance has halted their proper utilization (Knecht et al. 2014). Therefore, there is a strong need to investigate herbal products used in traditional medicines as an alternative to develop novel antidiarrhoeal compounds (Ahmadu et al. 2007).

Traditional medicine plays an essential contribution in primary health care needs in developing nations to maintain health (Martins and Brijesh 2018). Medicinal plants have been employed to manage many pathological disorders worldwide. About $60 \%$ of people worldwide rely on herbal preparations to manage different diseases (Ogbonnia et al. 2009). In rural areas of developing nations, herbal products serve as the main source of medicines. The scientific investigation of medicinal plants and their products as per traditional claims could form a basis for drug discovery (Ahmad et al. 2021). Herbal medicines and their derivatives (extract or pure compounds) serve as a huge array for discovering new therapeutic agents against many diseases (Yuet Ping et al. 2013). The international communities such as World Health Organization (WHO) have motivated the use of herbal plants to manage different diseases (Monteiro et al. 2018). However, there is inadequate scientific information to validate the claimed therapeutic activities of many plant-derived medicinal products (Baliga et al. 2011; Mukherjee et al. 2017; Zahoor et al. 2017).

Many plant-derived products worldwide have been claimed to be effective against diarrhoea (De La Fuente et al. 2008). The WHO advocates the use of herbal preparations to manage diarrhoea (Ezeja et al. 2012). In some developing nations, medicinal plants remain the only affordable and available option for treating diarrhoea (Njume and Goduka 2012). Likewise, in Nigeria and other African nations, herbal medicines have been commonly utilized against the disease (Okpara et al. 2017). Many studies have validated the claimed antidiarrhoeal potential of many herbal medicines for their antimotility and antisecretory effects, which could serve as a basis to develop novel antidiarrhoeal substance (Chaddha et al. 2013). Besides, it becomes vital for scientific investigations to be conducted on these herbal drugs with promising antidiarrhoeal efficacy, especially in economically constrained nations (Nduikui et al. 2013).

The plant Hymenocardia acida (Euphorbiaceae) as a shrub is approximately $9 \mathrm{~m}$ in height. The bark is smooth and pinkish-brown, which eventually turns to grey or pale brown later (Hyacinth and Nwocha 2011). The name of this plant (Hymenocardia) originated from the Greek word Hymen, meaning membrane, and Kardia, meaning heart. The plant's fruit is heart-shaped, covered by a transparent membrane (Tor-Anyin et al. 2013). Therefore, the plant is called a heart plant in English. The local name of the plant in Hausa is Jan Yaro, Yawa Satoje in Fulfulde, ikagala in Igbo and orunpa in Nigeria's Yoruba languages (Ibrahim et al. 2007a, b; Tor-Anyin et al. 2013).

The stem bark of Hymenocardia acida has been utilized for treating various ailments such as fever, diarrhoea, dysentery, mouth infections, muscular pain, headache, jaundice, hypotension, diabetes, epilepsy, schizophrenia and sickle cell anaemia (Tor-Anyin et al. 2013). In addition, the decoction of stem bark of Hymenocardia acida 
is utilized for dysentery and diarrhoea management (TorAnyin et al. 2013).

The plant Hymenocardia acida contains several phytochemical compounds. For instance, the phytochemical investigation on the stem bark of Hymenocardia acida indicated tannins, saponins, flavonoids, cardiac glycosides, alkaloids, anthraquinones, terpenes and steroid (Sofidiya et al. 2010). Ibrahim et al. (2007a, b) also reported tannins, saponins, flavonoids, cardiac glycosides, alkaloids, steroids, resins and terpenes in the stem bark of the plant. The aqueous stem bark of the plant contains saponins, glycosides and tannins (Ukwe 2004). Igoli and Alexander (2008) identified betulinic acid, friedelan3 -one, lupeol, stigmasterol $\beta$-sitosterol, oleic acid and the fatty acid in the stem bark of Hymenocardia acida. Starks et al. (2014) isolated chromene and chromane stilbenoids such as hymenocardichromanic acid from the leaves of the plant. Also, cyclopeptide alkaloids including hymenocardine, hymenocardinol, hymenocardine $\mathrm{N}$-oxide and hymenocardine were isolated from the root bark of Hymenocardia acida (Tuenter et al. 2016).

Keeping in view the ethnomedicinal application of Hymenocardia acida and its therapeutic potentials for the management of diarrhoea, we conducted this study to evaluate the antidiarrhoeal actions and potential mode of pharmacological action of the methanol stem bark extract of Hymenocardia acida to stimulate further research to discover novel bioactive compounds for use against diarrhoea.

\section{Methods}

\section{Collection and authentication of the plant}

The plant Hymenocardia acida was obtained from Galadimawa Area of Kaduna State, Nigeria, and authenticated (voucher number: 1275) at the Herbarium facility of the Botany Department, Ahmadu Bello University (ABU), Zaria, Nigeria.

\section{Laboratory animals}

Swiss albino mice (18-24 g) of both gender, three male New Zealand rabbits $(2-2.5 \mathrm{~kg})$ and three male guinea pigs $(300-500 \mathrm{~g})$, were sourced from the experimental animal facility of Pharmacology and Therapeutics Department of ABU, Zaria, Nigeria. The animals were kept in a proper laboratory environment (room temperature $22 \pm 3{ }^{\circ} \mathrm{C}$, relative humidity $30-70 \%$ with 12 -h light and 12-h dark cycle) for 2 weeks to acclamatisz to the laboratory environment before starting the experiment. Adequate animal feed was ensured with access to water sufficiently. The permission to conduct the study was granted by the Ahmadu Bello University Ethical Committee on Animal Use and Care Research Policy (permission number: ABUCAUC/2016/003). The experiment was executed as per the guidelines set by Animal Research: Reporting of In Vivo Experiments (ARRIVE). After completing the experimental procedures, all the animals were anaesthetized with chloroform and quickly euthanized by cervical dislocation. They were immediately buried deeply according to the institutional guideline for proper disposal of laboratory animals remains.

\section{Chemicals and reagents}

The drugs and chemicals utilized for this experiment include acacia gum powder (Evans Medical Lt Speke, Liverpool), activated charcoal (Ultracarbon powder-Merck KGaA Darmstadt, Germany), Castor oil (Bell and Sons, Southport PR9 AL, England), loperamide (Imodium ${ }^{\circledR}$, Jansen Pharmaceuticals, Pakistan) and distilled water. The acetylcholine, histamine, methanol and chloroform were obtained from Sigma Chemical Co. USA).

\section{Extraction procedure}

The stem bark of Hymenocardia acida was subsequently dried under the shade and periodically weighed until a uniform weight was obtained. The stem bark, after drying was pulverized into a fine powder with the aid of mor$\operatorname{tar}$ and pestle. $1200 \mathrm{~g}$ of the size-reduced plant material was extracted for $72 \mathrm{~h}$ with $70 \% v / v$ aqueous methanol) with Soxhlet apparatus. The extract was concentrated to dryness by removing the solvent on a water bath set at $45^{\circ} \mathrm{C}$. After drying, the extract was weighed and appropriately kept in a well-labelled container as "methanolic stem bark extract of Hymenocardia acida" (MEHA). The extractive value of the MEHA was determined based on the following relationship:

$$
\begin{aligned}
& \text { Percentage yield (\%) } \\
& \qquad=\frac{\text { Weight of the crude extract }(\mathrm{g})}{\text { Weight of the powdered plant material }(\mathrm{g})} \times 100
\end{aligned}
$$

\section{Phytochemical determination}

The phytochemical determination was conducted to check phytochemical constituents such as alkaloids, tannins, anthraquinones, flavonoids, saponins, steroids, triterpenes and cardiac glycosides in the MEHA according to the standard methods (Sofowora 1993).

\section{Acute toxicity studies}

The acute toxic effects of the MEHA were determined based on the protocols reported by the organization for Economic Co-operation and Development (OECD) 423 (OECD 2001). The median lethal dose $\left(\mathrm{LD}_{50}\right)$ after oral administration was investigated using non-pregnant and nulliparous female mice. The mice were kept in polypropylene cages and allowed to acclimatize for $48 \mathrm{~h}$ 
before the commencement of the experiment. They were deprived of food for $4 \mathrm{~h}$ before the oral administration of the MEHA with the provision of water sufficiently. Three mice were orally administered $2000 \mathrm{mg} / \mathrm{kg}$ of MEHA. Following the extract's administration, food but not water was withheld for $2 \mathrm{~h}$. The mice were carefully checked for any signs of toxic effects of the extract such as physical and behavioural changes such as tremor, convulsion, salivation, lacrimation, diarrhoea, lethargy, sleep, respiratory, the onset of toxic effects if any and length of the total duration of toxic signs as well as death once every 30 min within the first $4 \mathrm{~h}$ and subsequently every day for 14 days.

\section{In vivo antidiarrhoeal studies \\ Castor oil-induced diarrhoea in mice}

The experimental protocol previously reported by Awouters and colleagues (1978) was employed. Mice were fasted for $18 \mathrm{~h}$ and categorized randomly into five different groups $(n=6)$. The mice in group I were pretreated with distilled water $(10 \mathrm{ml} / \mathrm{kg})$. The groups II, III and IV were pretreated with graded doses of MEHA (150 mg, $300 \mathrm{mg}$ and $600 \mathrm{mg}$ ), respectively, while group $\mathrm{V}$ received the loperamide (conventional antidiarrhoeal drug) at the dose of $3 \mathrm{mg} / \mathrm{kg}$. All the pretreatment were via the oral route. One hour after the pretreatment, castor oil $(0.5 \mathrm{ml})$ was orally administered to each mouse to induce diarrhoea. Then the animals were kept in separate cages lined with white filter paper for an observation period of $4 \mathrm{~h}$. The parameters observed were the onset of diarrhoea, frequency of watery stool and a number of wet faeces. The percentage protection against diarrhoea was calculated as follows:

$$
\% \text { inhibition of diarrhoea }=\frac{\text { No of wet faeces in the control group }- \text { No of wet faeces in a test group }}{\text { Total No of wet faeces in the control group }} \times 100
$$

\section{Intestinal fluid accumulation test in mice}

The experimental protocol previously reported by Robert et al. (1975) was used. The mice were fasted for $18 \mathrm{~h}$ and categorized randomly into five separate groups $(n=6)$. The mice in group I were pretreated with distilled water $(10 \mathrm{ml} / \mathrm{kg})$. The groups II, III and IV received graded doses of MEHA (150 mg, $300 \mathrm{mg}$ and $600 \mathrm{mg}$ ), respectively, while group $\mathrm{V}$ received loperamide (conventional antidiarrhoeal drug) at the dose of $3 \mathrm{mg} / \mathrm{kg}$. After $60 \mathrm{~min}$ of the pretreatments, castor oil $(0.5 \mathrm{ml})$ was administered to the animals orally. Then $30 \mathrm{~min}$ after administration of the castor oil, the mice in all the groups were anaesthetized using light ether anaesthesia and euthanized by cervical dislocation. Subsequently, the abdomen of each mouse was dissected with the aid of dissecting set, and the small intestine was cut from pylorus to caecum. The content of the small intestine from each mouse was milked into a calibrated syringe to determine its volume in millilitres $(\mathrm{ml})$ and recorded. The volume of the intestinal fluid obtained from the distilled water treated group was compared with the groups that received the extract and the loperamide. Percentage reduction in volume was determined as follows:

$$
\% \text { decrease in the volume of intestinal content }=\frac{A-B}{A} \times 100
$$

where $A=$ volume of intestinal content in the control group; $B=$ volume of intestinal content in the test group.

\section{Charcoal meal test in mice}

The intestinal transit was determined on the basis of the experimental protocols reported by Di Carlo et al. (1993). The mice were deprived of food for $18 \mathrm{~h}$ and divided randomly into five separate groups $(n=6)$. The group I animals were pretreated with distilled water $(10 \mathrm{ml} / \mathrm{kg})$ orally. Groups II, III and IV received the graded doses of MEHA (150 mg, $300 \mathrm{mg}$ and $600 \mathrm{mg}$ ), respectively, while group $\mathrm{V}$ received atropine sulphate (conventional antimotility agent) at $3 \mathrm{mg} / \mathrm{kg}$. After sixty minutes of the respective treatments, each mouse received a $0.5 \mathrm{ml}$ charcoal meal (5\% activated charcoal suspension in $0.5 \%$ acacia). Subsequently, $30 \mathrm{~min}$ following the oral administration of the charcoal meal, the animals in all the groups were anaesthetized using light ether anaesthesia and euthanized by cervical dislocation. Each animal's abdomen was opened with the aid of dissecting set, and the small intestine was removed from pylorus to caecum and placed lengthwise on moist filter paper. The distance moved by the charcoal meal in relation to the small intestine's total length was determined and recorded using a calibrated ruler. The peristaltic index and percentage inhibition of charcoal movement were calculated as follows:

\% Peristaltic index of charcoal meal

$$
=\frac{\text { distance travel by charcoal meal }(\mathrm{cm})}{\text { Total length of the small intestine }(\mathrm{cm})} \times 100
$$

$\%$ inhibition of charcoal movement $=\frac{A-B}{A} \times 100$ 
$A=$ mean movement of charcoal meal in the control group; $B=$ mean movement of charcoal meal in the test group.

\section{In vitro antidiarrhoeal studies}

Actions of methanol bark extract of Hymenocardia acida on rabbit jejunum

An adult male rabbit was starved of feed but not water for about $18 \mathrm{~h}$. It was then anaesthetized by light ether anaesthesia and euthanized. The abdomen of the rabbit was opened, and part of the jejunum $(4 \mathrm{~cm}$ long) was cut and dissected free of adhering mesentery. The tissue was subsequently suspended in a $25 \mathrm{ml}$ organ bath that contains tyrode solution and left to stabilize for $30 \mathrm{~min}$. The effects of acetylcholine $\left(2 \times 10^{-5}-16 \times 10^{-5} \mathrm{mg} /\right.$ $\mathrm{ml})$ and the MEHA $\left(8 \times 10^{-2}-640 \times 10^{-2} \mathrm{mg} / \mathrm{ml}\right)$ on the jejunum were investigated. The tissue was left to rest before adding the next drug. The contact time for each concentration of the test substance was $30 \mathrm{~s}$, then subsequently washing three times with a tyrode solution. The responses produced by acetylcholine alone and the interaction between the MEHA and acetylcholine were then recorded using a microdynamometer set at $3.0 \mathrm{mV}$ and a speed of $24 \mathrm{~mm} / \mathrm{min}$.

\section{Actions of methanol bark extract of Hymenocardia acida on guinea pig ileum}

A similar protocol was adopted as that of the effects of the MEHA on isolated rabbit jejunum as described above (2.8.1). The effect of histamine $\left(2 \times 10^{-5}-16 \times 10^{-5} \mathrm{mg} /\right.$ $\mathrm{ml})$ and the MEHA $\left(8 \times 10^{-2}-640 \times 10^{-2} \mathrm{mg} / \mathrm{ml}\right)$ were determined on guinea pig ileum. The response elicited by histamine alone and the interaction between the MEHA and histamine were subsequently recorded.

\section{Data analysis}

The data were analysed using SPSS software and presented as the mean \pm standard error of the mean (SEM) in tables and graphs. One-way analysis of variance
(ANOVA) was utilized to compare the means of the groups, followed by Dunnett's post hoc test for multiple comparisons. The outcomes were considered significant at $p \leq 0.05$.

\section{Results}

The extractive value of methanol bark extract

of Hymenocardia acida

The dried extract weight obtained was $107 \mathrm{~g}$ after the extraction of $1200 \mathrm{~g}$ of the plant material, representing an extractive value of $8.92 \%$.

\section{Phytochemical investigation}

Phytochemical determination of the crude MEHA showed tannins, steroids, terpenes, saponins, alkaloid and flavonoids.

\section{Acute toxicity investigation of methanol bark extract of Hymenocardia acida}

The MEHA at $2000 \mathrm{mg} / \mathrm{kg}$ showed no mortality and clear sign of toxic effects over the period of the study (14 days). Hence, the median lethal dose $\left(\mathrm{LD}_{50}\right)$ of the MEHA after oral administration could be more than $2000 \mathrm{mg} / \mathrm{kg}$.

\section{Castor oil-induced diarrhoea in mice}

The castor oil produced diarrhoea copiously at $(27.20 \pm 4.71 \mathrm{~min})$ in the distilled water treated group. The MEHA produced a remarkable $\left(p^{<} 0.05\right)$ increase in the onset of diarrhoea in order of increasing dose relative to the distilled water treated group. Besides, a decrease in the number of wet faeces in relation to the negative control group was observed. It also produced dose-dependent inhibition of diarrhoea (23.08, 53.85 and $80.77 \%)$. The standard antidiarrhoeal drug loperamide showed a significant elevation in the onset of diarrhoea $(93.80 \pm 2.31 \mathrm{~min})$ and reduced the number of diarrhoea faeces $(0.20 \pm 0.20)$ when related to the group that received distilled water (Table 1 ).

Table 1 Action of methanol bark extract of Hymenocardia acida on castor oil-induced diarrhoea in mice

\begin{tabular}{|c|c|c|c|c|}
\hline Treatments (mg/kg, p.o) & $\begin{array}{l}\text { Onset of diarrhoea } \\
\text { (min) }\end{array}$ & Number of dry faeces & Number of wet faeces & $\begin{array}{l}\text { Percentage } \\
\text { inhibition (\%) }\end{array}$ \\
\hline DW $10 \mathrm{ml} / \mathrm{kg}$ & $27.20 \pm 4.71$ & $2.60 \pm 0.98$ & $5.20 \pm 0.49$ & \\
\hline MEHA (150) & $76.80 \pm 7.35^{*}$ & $2.00 \pm 0.32$ & $4.00 \pm 0.71$ & 23.08 \\
\hline MEHA (300) & $82.80 \pm 3.06^{*}$ & $1.20 \pm 0.80$ & $2.40 \pm 0.68^{*}$ & 53.85 \\
\hline MEHA (600) & $83.20 \pm 6.36^{*}$ & $1.00 \pm 0.45$ & $1.00 \pm 0.45^{*}$ & 80.77 \\
\hline LOP (3) & $93.80 \pm 2.31^{*}$ & $1.00 \pm 0.32$ & $0.20 \pm 0.20^{*}$ & 96.15 \\
\hline
\end{tabular}

The values are represented as mean $\pm \mathrm{SEM} ;{ }^{*} p<0.05$, compared to the distilled water group (one-way ANOVA followed by Dunnett's post hoc test), DW $=$ distilled water, $\mathrm{MEHA}=$ methanol stem bark extract of $H$. acida, $\mathrm{LOP}=$ loperamide, $p .0=$ per oral, $n=6$ 
$\%$ inhibition of diarrhoea $=\frac{\text { No of wet faeces in the control group }- \text { No of wet faeces in a test group }}{\text { Total No of wet faeces in the control group }} \times 100$

For example, the percentage inhibition of diarrhoea in the group treated with $150 \mathrm{mg} / \mathrm{kg}$ of the MEHA can be illustrated as follows:

$$
\begin{aligned}
& \text { \% inhibition of diarrhoea }(150 \mathrm{mg} / \mathrm{kg})=\frac{5.20-4.00}{5.20} \times 100 \\
& \% \text { inhibition of diarrhoea }(150 \mathrm{mg} / \mathrm{kg})=23.08 \%
\end{aligned}
$$

\section{Intraluminal fluid accumulation}

The MEHA (150, 300 and $600 \mathrm{mg} / \mathrm{kg}$ ) exerted a significant $\left(p^{<} 0.05\right)$ and non-dose-dependent reduction in the volume of intestinal fluid $(0.12 \pm 0.02,0.15 \pm 0.02$ and $0.11 \pm 0.05 \mathrm{ml}$ ) by $60 \%, 50 \%$ and $63.33 \%$, respectively, in relation to the group that received the distilled water $(0.30 \pm 0.02 \mathrm{ml})$. Also, the group treated with loperamide significantly reduced the intestinal fluid volume by $66.66 \%$ compared to the control group (Table 2).

$\%$ inhibition in the volume of intestinal content $=\frac{A-B}{A} \times 100$

Table 2 Actions of methanol bark extract of Hymenocardia acida on enteropooling in mice

\begin{tabular}{lll}
\hline Treatments $(\mathbf{m g} / \mathbf{k g})$ & $\begin{array}{l}\text { Volume of intestinal } \\
\text { content }(\mathbf{m l})\end{array}$ & $\begin{array}{l}\text { Percentage } \\
\text { inhibition (\%) }\end{array}$ \\
\hline DW (10 ml/kg) & $0.30 \pm 0.02$ & - \\
MEHA (150) & $0.12 \pm 0.02^{*}$ & 60.00 \\
MEHA (300) & $0.15 \pm 0.02^{*}$ & 50.00 \\
MEHA (600) & $0.11 \pm 0.05^{*}$ & 63.33 \\
LOP (3) & $0.10 \pm 0.01^{*}$ & 66.66 \\
\hline
\end{tabular}

The values represented as Mean \pm SEM; ${ }^{*} p<0.05$, compared to the distilled water group (one-way ANOVA followed by Dunnett's post hoc test), $\mathrm{DW}=$ distilled Water, $\mathrm{MEHA}=$ methanol stem bark extract of $H$. acida, LOP $=$ loperamide, $p . o=$ per oral,$n=6$ where $A=$ volume of intestinal content in the control group; $B=$ volume of intestinal content in the test group.

For example, the percentage inhibition in a volume of intestinal content in the group treated with $150 \mathrm{mg} / \mathrm{kg}$ of the MEHA can be illustrated as follows:

$\%$ inhibition in volume of intestinal content $(150 \mathrm{mg} / \mathrm{kg})$

$$
=\frac{0.30-0.12}{0.30} \times 100
$$

$\%$ inhibition of intestinal content volume $(150 \mathrm{mg} / \mathrm{kg})$

$$
=60.00 \%
$$

\section{Effects of Hymenocardia acida bark extract on intestinal motility in mice}

The MEHA at the doses of 150 and $300 \mathrm{mg} / \mathrm{kg}$ did not reduce the charcoal meal movement $(38.50 \pm 0.56$ and $38.25 \pm 2.42 \mathrm{~cm})$. However, the highest dose of the extract and atropine sulphate remarkably reduced the charcoal movement $(27.58 \pm 3.09$ and $27.91 \pm 2.78 \mathrm{~cm})$ with respective percentage inhibition of the charcoal movement of $33.27 \% 32.47 \%$ as shown in Table 3.

$$
\% \text { inhibition of charcoal movement }=\frac{A-B}{A} \times 100
$$

$A=$ mean movement of charcoal meal in the control group; $B=$ mean movement of charcoal meal in the test group.

\begin{tabular}{|c|c|c|c|c|}
\hline Treatments (mg/kg) & Length of intestine $(\mathrm{cm})$ & Movement of charcoal $(\mathrm{cm})$ & Peristaltic index (\%) & $\begin{array}{l}\text { Percentage } \\
\text { inhibition (\%) }\end{array}$ \\
\hline DW $10 \mathrm{ml} / \mathrm{kg}$ & $46.38 \pm 1.18$ & $41.33 \pm 1.08$ & 89.11 & \\
\hline HA (150) & $45.83 \pm 1.08$ & $38.50 \pm 0.56$ & 84.00 & 06.85 \\
\hline HA (300) & $50.93 \pm 1.60$ & $38.25 \pm 2.42$ & 75.10 & 07.45 \\
\hline HA (600) & $45.17 \pm 1.86$ & $27.58 \pm 3.09^{*}$ & 58.46 & 33.27 \\
\hline $\operatorname{ATR}(3)$ & $44.87 \pm 2.30$ & $27.91 \pm 2.78^{*}$ & 62.22 & 32.47 \\
\hline
\end{tabular}

For example, the percentage inhibition of charcoal meal movement in the group treated with $150 \mathrm{mg} / \mathrm{kg}$ of the MEHA can be illustrated as follows:

Table 3 The actions of methanol bark extract of Hymenocardia acida on gastric transit time in mice

The values are represented as mean $\pm \mathrm{SEM} ;{ }^{*} p<0.05$, compared to the distilled water group (One-way ANOVA followed by Dunnett's post hoc test), DW $=$ distilled water, $\mathrm{MEHA}=$ methanol stem bark extract of $H$. acida, ATR = atropine sulphate, $p . o=$ per oral, $n=6$ 


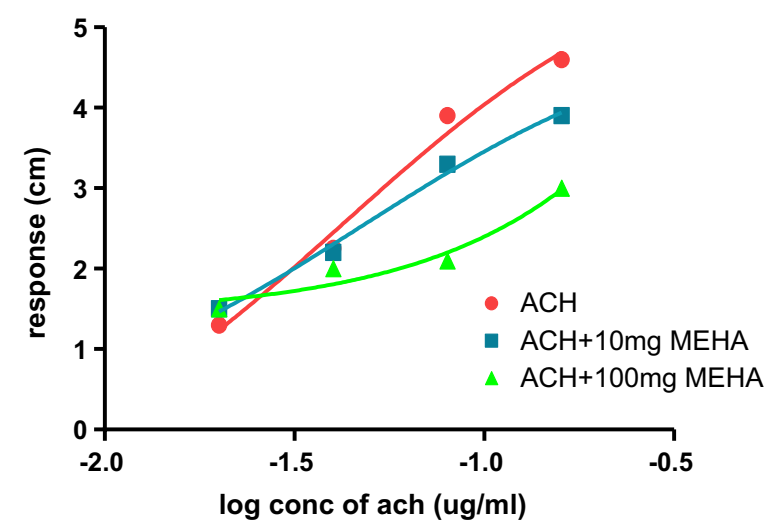

Fig. 1 The action of methanol bark extract of Hymenocardia acida on acetylcholine-induced contraction on isolated rabbit jejunum, $n=3$

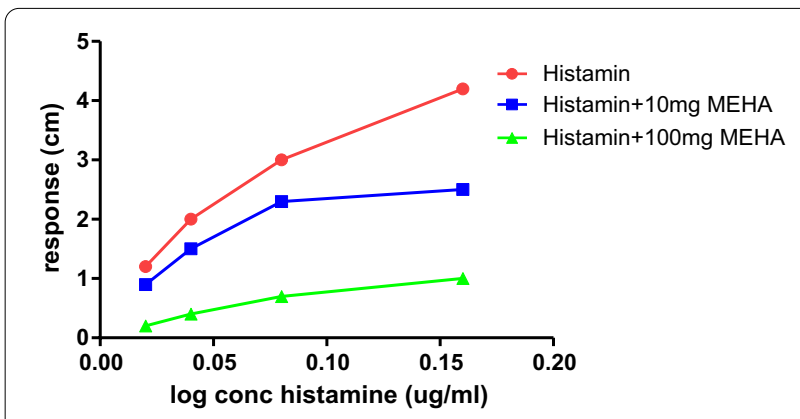

Fig. 2 The actions of the methanol stem bark extract of Hymenocardia acida on histamine-induced contraction on guinea pig ileum, $n=3$

$$
\begin{aligned}
& \text { \% inhibition of charcoal movement }(150 \mathrm{mg} / \mathrm{kg}) \\
& \quad=\frac{41.33-38.50}{41.33} \times 100 \\
& \text { \% inhibition of charcoal movement }(150 \mathrm{mg} / \mathrm{kg}) \\
& \quad=6.85 \%
\end{aligned}
$$

\section{Actions of the methanol stem bark extract of Hymenocardia acida on rabbit jejunum (isolated tissue)} The MEHA $\left(8 \times 10^{-2}-640 \times 10^{-2} \mathrm{mg} / \mathrm{ml}\right)$ significantly revealed a reduction in the spontaneous contraction of the isolated rabbit jejunum in order of increasing concentration. Besides, the MEHA at $8 \times 10^{-2}-640 \times 10^{-2} \mathrm{mg} / \mathrm{ml}$ when combined with acetylcholine $\left(2 \times 10^{-5}-16 \times 10^{-5} \mathrm{mg} / \mathrm{ml}\right)$ elicited a concentration-dependent abolition of the contraction caused by acetylcholine in a non-parallel rightward shift (Fig. 1).
The actions of methanol bark extract of Hymenocardia acida on isolated guinea pig ileum

The MEHA $\left(8 \times 10^{-2}-640 \times 10^{-2} \mathrm{mg} / \mathrm{ml}\right)$ produced remarkable $\left(p^{<} 0.05\right)$ and concentration-dependent relaxation of guinea pig ileum. It also significantly inhibited contraction caused by histamine $\left(2 \times 10^{-5}-16 \times 10^{-5} \mathrm{mg} /\right.$ $\mathrm{ml}$ ) on guinea pig ileum. The histamine showed a concentration-dependent increase in the rate of contraction of the guinea pig ileum. Similar to the extract's effects on acetylcholine, the extract shifted the histamine concentration-response curve (Fig. 2).

\section{Discussion}

Many scientific investigations were conducted to validate the reported folkloric claims of herbal products to treat diarrhoea and determine their effects on intestinal motion and fluid and electrolyte secretory activity (Chaddha et al. 2013). The plant Hymenocardia acida has been reported in traditional medicine to be used against diarrhoea (Tor-Anyin et al. 2013). Therefore, the antidiarrhoeal activities and probable mechanisms of action of the bark extract of Hymenocardia acida against diarrhoea were investigated to validate its folkloric claim as a basis for further research to develop novel antidiarrhoeal compounds.

The evaluation of the acute toxic effects of chemical agent is essential to determine the $\mathrm{LD}_{50}$ of chemical substances, and it gives a guide on the doses to be used in the subsequent experimental procedures (De Oliveira et al. 2017). The use of doses less than or equal to $30 \%$ of the reported $\mathrm{LD}_{50}$ are relatively safe for pharmacological screening in experimental animals (Vongtau et al. 2004). Besides, the investigation of the $\mathrm{LD}_{50}$ is the initial phase in assessing the toxicity effects of chemical substances. For example, after the acute administration of the MEHA (2000 mg/kg) in this study, no death and evident signs of toxicity were determined over the duration of the 14 days. The finding suggested that the oral $\mathrm{LD}_{50}$ of the MEHA was more than $2000 \mathrm{mg} / \mathrm{kg}$. Besides, the extract could be safe relatively after acute administration. Similarly, Obidike and team members in 2011 showed the safety of Hymenocardia acida leaves after acute and chronic administration (Obidike et al. 2011).

The pathogenesis of diarrhoea includes increased luminal osmotic pressure, increased intestinal fluid and electrolyte secretion, reduction in absorption, and increased intestinal hypermotility (Umer et al. 2013). Therefore, therapeutic agents with intestinal hypermotility and hypersecretory inhibitory actions have been utilized against diarrhoea (Mekonnen et al. 2018). In this experiment, we reported the antidiarrhoeal potentials of the bark extract of Hymenocardia acida using castor 
oil-induced diarrhoea, intestinal fluid accumulation, gastrointestinal motion test, as well as in vitro studies on rabbit jejunum and guinea pig ileum.

Castor oil is metabolized in the intestine and causes the production and release of a hydroxylated fatty acid (ricinoleic acid) by intestinal lipase. The ricinoleic acid provoked intestinal irritation and inflammation, resulting in prostaglandins' (PG) release, which subsequently increases the intestinal motility and hypersecretion (Brijesh et al. 2009). The PG released promotes intestinal smooth muscle contraction, vasodilatation and intestinal mucus secretion that eventually cause diarrhoea (Brijesh et al. 2009). The overall effects are increased fluid and water secretion and increased intestinal transit time, diarrhoea frequency, and increased wet faeces (Ezeja et al. 2012). The agents that inhibit PG biosynthesis could delay diarrhoea (Brijesh et al. 2009). Therefore, on account of this study, the MEHA could possess its antidiarrhoeal activity by stimulating fluid and water reabsorption, increased small intestinal residence time, decreased intestinal hypersecretion and prevented prostaglandins' action associated with the pathophysiology of diarrhoea. The MEHA could also inhibit PG biosynthesis as well as anti-inflammatory potentials. Research by Sofidiya and colleagues (2010) reported the anti-inflammatory action of Hymenocardia acida by inhibiting PG's biosynthesis. In an experiment conducted by Ezeja et al. (2012), the leaves extract of Pterocarpus erinaceus inhibited the diarrhoea induced by castor oil. Similarly, Ahmadu and team members (2007) reported the inhibitory actions of Ficus sycomorus and Daniellia oliveri against diarrhoea induced by castor oil. The fruit of Annona muricata dose-dependently inhibited castor oil-induced diarrhoea (Afroz et al. 2020).

The ricinoleic acid is polar in nature and therefore poorly absorbed; thus, it changes the small intestinal permeability to fluid and electrolyte, activates peristaltic movement in the intestines and eventually causes fluid accumulation (Adeyemi et al. 2011). From the findings of the current experiment, the inhibitory action of the MEHA on the intestinal fluid accumulation could be attributed to the prevention of PG biosynthesis, decrease in the intestinal fluid secretion and promotion of fluid and electrolytes reabsorption as observed in the castor oil-induced diarrhoea. Based on the study reported by Dahiru et al. (2006), the methanolic root extract of $Z$. Mauritiana significantly reduced intestinal fluid accumulation. In another research by Ahmad et al. (2020a, b), the leaves extract of Combretum hypopilinum also inhibited the small intestinal fluid accumulation.

Loperamide produces its action as an agonist on the $\mathrm{mu}(\mu)$ opioid receptor in the large intestine's myenteric plexus. This drug possesses antidiarrhoeal action by reducing the contractility of the myenteric plexus and diminishes the tone of the intestinal smooth muscle (Hughes et al. 1982). It also hinders the release of acetylcholine from the enteric nervous and attenuates the intestine's peristaltic activity, which increases the intestinal residence time and more fluid and electrolytes reabsorption (Lutterodt 1992). Overall, loperamide produces antidiarrhoeal action due to its antimotility and antisecretory activities (Holzer 2009). In a study by Awouters et al. (1978), loperamide inhibited PG-induced diarrhoea. In the present work, the loperamide halted the diarrhoea and fluid accumulation in the intestine. Therefore, the MEHA could possess its antidiarrhoeal action in a similar manner to the loperamide.

The activated charcoal cannot be absorbed in the intestine and, therefore, hinders the absorption of chemicals and other substances by the adsorption process (Bello et al. 2016). Going by the outcome of this research, the remarkable reduction in the charcoal motion elicited by the MEHA may be related to its intestinal hypermotility inhibitory effect as a result of reduced intestinal transit, increased intestinal staying time and promotion of water and electrolyte reabsorption (Shoba and Molly 2014). It is well known that anticholinergic agents have intestinal antimotility activity (Mahesh et al. 2010). Hence, the extract's significant antimotility action in the present work could be related to its anticholinergic effect. Similar to the outcome of the present work, several antidiarrhoeal agents and plant extracts elicit their pharmacological activity by reducing intestinal transit (Monirul Islam et al. 2013). For instance, research has shown that the leaves of Combretum hypopilinum significantly reduced the intestinal hypermotility (Ahmad et al. 2020a, b). Besides, leaves of Syzygium cumini L. (Myrtaceae) inhibited the charcoal movement in the gastrointestinal motility test (Monteiro et al. 2018). Calzada and fellow researchers (2010) also revealed the intestinal hypermotility inhibitory actions of several Mexican medicinal plants. In a separate experiment by Riaz et al. (2020), Ficus palmate elicited an antimotility effect.

Acetylcholine released as the major neurotransmitter from the autonomic nervous system (ANS) stimulates the intestinal smooth muscles due to muscarinic receptors' action (Bello et al. 2016). The activation of the muscarinic receptors, specifically $\mathrm{M}_{3}$ subtype by acetylcholine stimulates phospholipase C (PLC) that subsequently caused the production of diacylglycerol (DAG) and inositol triphosphate $\left(\mathrm{IP}_{3}\right)$. The $\mathrm{IP}_{3}$ stimulates the intracellular calcium ion $\left(\mathrm{Ca}^{2+}\right)$ and mobilizes the release of $\mathrm{Ca}^{2+}$ from other tissues via the $\mathrm{Ca}^{2+}$ sensitive channels. DAG phosphorylates different proteins by stimulating protein kinase $C$, which subsequently activates the non-selective 
cationic channels and stimulates voltage-dependent calcium channel (Sanders 2008). Based on the result of this work, acetylcholine elicited a contractile effect on the rabbit jejunum in order of increasing concentration due to its effect on the muscarinic receptor. However, the MEHA antagonized the acetylcholine action on rabbit jejunum contraction that could be related to an anticholinergic activity which is evident from the concentration-response curve (CRC) of the extract on the acetylcholine-elicited contraction. The MEHA shifted the CRC of the acetylcholine to the right and suppressed its maximum response. Riaz et al. (2020) reported the Ficus palmate's ability to inhibit the contractility of rabbit jejunum. Research reported by Bello and team members (2016) has shown the capability of Nymphaea lotus rhizome to have demonstrated a contractile action and enhanced the tone of the isolated rabbit's contraction jejunum at low concentration. However, it significantly reduced the spontaneous contractility of the rabbit jejunum at a high concentration. In a similar study by Khan et al. (2011), Salvia officinalis produced relaxation of the rabbit jejunum in order of increasing concentration.

Another possible mechanism for the spasmolytic activity of the MEHA in this study could be through the inhibition of histamine receptors. Histamine receptors are abundant in the lumen and mucosal lining of the gastrointestinal tract in enterochromaffin-like (ECL) cells (Bello et al. 2016). The stimulation of the histamine receptors on smooth muscles causes concentration-dependent membrane depolarization and excitation (Bello et al. 2016). Furthermore, the histamine binds to the histamine $\left(\mathrm{H}_{1}\right)$ receptor and elicits contractile action of the isolated guinea pig ileum (Bertaccini et al. 1979). Based on the findings in this study, the extract elicited remarkable relaxation on the isolated guinea pig ileum. This is evident from the CRC graph of the extract on the contraction induced by the histamine on the isolated guinea pig ileum. From the graph, the extract moved the histamine CRC to the right to suppress the histamine's maximum effect. Similarly, the aqueous leaves extract of Tagetes lucida inhibited guinea ileum's spontaneous contractions (Ventura-Martinez et al. 2020).

The in vitro findings in this study have shown that the extract's effect could be non-specific since it affects both the muscarinic and histaminergic receptors. Interestingly, most $\mathrm{H}_{1}$ receptor antagonists are reported to inhibit acetylcholine responses by blocking the muscarinic acetylcholine receptors (Saikia et al. 2017). Therefore, it could be possible that the MEHA possesses phytochemicals that could have elicited the antihistaminergic and anticholinergic effects observed. Furthermore, it was reported that the phytochemical compounds present in herbal products could antagonize acetylcholine and histamine-induced intestinal activation (Saikia et al. 2017). For example, Ammon et al. (2006) documented the spasmolytic and atonic actions of an herbal product (iberogast ${ }^{\circledR}$ ) used against dyspepsia and irritable bowel syndrome on the contraction produced by acetylcholine and histamine. Similar to the outcome of the present work, the rhizome of Nymphaea lotus attenuated the contraction exerted by acetylcholine and histamine on isolated rabbit jejunum and guinea pig ileum, respectively (Bello et al. 2016).

Several phytochemical compounds such as flavonoids, saponin, tannins and alkaloids have relaxant activity on the intestinal smooth muscles (Ali and Ali Shah 2011). Studies have shown that alkaloid, glycoside, terpenoids prevent the production and release of autocoids and PG implicated in diarrhoea, whereas flavonoids inhibit acetylcholine release in the GIT, prevent intestinal motility and hypersecretion (Dosso et al. 2012). Also, flavonoids antagonize $\mathrm{PGE}_{2}$-induced intestinal hypersecretion (Dosso et al. 2012). The tannins protect the intestinal mucosa against $\mathrm{PGE}_{2}$-induced fluid accumulation, while saponins inhibit the histamine release in an ex vitro experiment (Mahesh et al. 2010). Due to the presence of flavonoids, steroids, terpenes, tannins, alkaloids and saponins in the MEHA, it could also possess intestinal smooth muscle relaxant action, prevent intestinal motility, hypersecretion and fluid accumulation, with an overall antidiarrhoeal activity.

\section{Conclusion}

The outcome of this work has revealed that the MEHA has phytochemical compounds with potential antidiarrhoeal activity, therefore justifying its ethnopharmacological claim for use in the management of diarrhoea. Hence, it is recommended for more research be conducted on this medicinally important plant to uncover the molecular basis of its antidiarrhoeal action in an attempt to discover and develop novel antidiarrhoeal compounds.

\section{Plant authentication}

The plant was authenticated at the Herbarium Section of the Department of Botany, Faculty of Life Sciences, Ahmadu Bello University, Zaria, Nigeria, (voucher number: 1275$)$ by comparing it with an existing specimen.

\section{Abbreviations}

ACH: Acetylcholine; ANOVA: Analysis of variance; ANS: Autonomic nervous system; $\mathrm{Ca}^{2+}$ : Calcium ion; CRC: Concentration-response curve; DAG: DiacylgIycerol; ECL: Enterochromaffin-like cells; GIT: Gastrointestinal tract; IP: Inositol triphosphate; $\mathrm{LD}_{50}$ : Median lethal dose; MEHA: Methanol stem bark extract of Hymenocardia acida; OECD: Organization for Economic Co-operation and Development; p.o: Per oral; PG: Prostaglandins; PLC: Phospholipase C; WHO: World Health Organization. 


\section{Acknowledgements}

The authors are thankful to all staff of the Department of Pharmacology and Therapeutics, Ahmadu Bello University, Zaria, Nigeria, for their support during the conduct of the research.

\section{Authors' contributions}

AMU contributed to conceptualization, investigation, data curation and writing-original draft. NMD contributed to supervision, project administration, review and validation. JY contributed to supervision, project administration, review and validation. MMA contributed to formal analysis and review. ZA contributed to writing and review. YMA contributed to writing and review. MHA contributed to writing - original draft and review. All the authors read and approved the final manuscript.

\section{Funding}

Not applicable.

\section{Availability of data and materials}

The datasets generated during and/or analysed during the current study are available from the corresponding author on reasonable request.

\section{Declarations}

\section{Ethics approval and consent to participate}

The experimental protocols were approved by the Ahmadu Bello University Ethical Committee on Animal Use and Care Research Policy (Protocol Number: ABUCAUC/2016/003) and conducted following the Animal Research: Reporting of In Vivo Experiments (ARRIVE) guidelines.

\section{Consent for publication}

Not applicable.

\section{Competing interests}

The authors declare that they have no competing interests.

\section{Author details}

'Department of Pharmacology, Bauchi State University, Gadau, Bauchi State, Nigeria. ${ }^{2}$ Department of Pharmacology and Therapeutics, Ahmadu Bello University, Zaria, Kaduna, Nigeria.

Received: 26 May 2021 Accepted: 11 June 2021

Published online: 23 June 2021

\section{References}

Adeyemi O, Oyeniyi O, Mbagwu H, Jackson C (2011) Evaluation of the gastrointestinal activity of the aqueous root extracts of Talinum triangulare. Res Pharmaceut Biotechnol 3(6):61-67. https://doi.org/10.5897/RPB.9000015

Afroz N, Ahsanul Hoq M, Jahan S, Mainul Islam M, Ahmed F, Shahid-Ud-Daula AFM, Hasanuzzaman M (2020) Methanol soluble fraction of fruits of Annona muricata possesses significant antidiarrheal activities. Heliyon 6(1):e03112. https://doi.org/10.1016/j.heliyon.2019.e03112

Ahmad MH, Zezi AU, Anafi SB, Danraka RN, Alhassan Z (2020a) Evaluation of antidiarrhoeal activity of methanol extract of Combretum hypopilinum Diels (Combretaceae) leaves in mice. Adv Pharmaceut J 5(2):54-61. https://doi.org/10.31024/apj.2020.5.2.3

Ahmad MH, Zezi AU, Bola AS, Alhassan Z, Mohammed M, Danraka RN (2020b) Mechanisms of antidiarrhoeal activity of methanol leaf extract of Combretum hypopilinum diels (Combretaceae): Involvement of opioidergic and (a1 and $\beta$ )-adrenergic pathways. J Ethnopharmacol 269:113750. https://doi.org/10.1016/j.jep.2020.113750

Ahmad MH, Jatau Al, Khalid GM, Alshargi OY (2021) Traditional uses, phytochemistry, and pharmacological activities of Cochlospermum tinctorium A. Rich (Cochlospermaceae): a review. Future J Pharmaceut Sci 7(1):1-13. https://doi.org/10.1186/s43094-020-00168-1

Ahmadu AA, Zezi AU, Yaro AH (2007) Anti-diarrheal activity of the leaf extracts of Daniellia Oliveri hutch and Dalz (Fabaceae) and Ficus sycomorus Mia
(Moraceae). Afr J Tradit Complement Altern Med 4(4):524-528. https:// doi.org/10.4314/ajtcam.v4i4.31246

Ali N, Ali Shah SW (2011) Antispasmodic activity of Teucrium stocksianum boiss. Pak J Pharm Sci 24(2):171-174

Ammon HPT, Kelber O, Okpanyi SN (2006) Spasmolytic and tonic effect of Iberogast ${ }^{\circledR}$ (STW 5) in intestinal smooth muscle. Phytomedicine 13:67-74. https://doi.org/10.1016/j.phymed.2006.08.004

Awouters F, Niemegeers CJE, Lenaerts FM, Janssen PAJ (1978) Delay of castor oil diarrhoea in rats: a new way to evaluate inhibitors of prostaglandin biosynthesis. J Pharm Pharmacol 30(1):41-45. https://doi.org/10.1111/j. 2042-7158.1978.tb13150.x

Baliga MS, Bhat HP, Baliga BRV, Wilson R, Palatty PL (2011) Phytochemistry, traditional uses and pharmacology of Eugenia jambolana Lam. (black plum): a review. Food Res Int 44(7):1776-1789. https://doi.org/10.1016/j. foodres.2011.02.007

Bello FH, Maiha BB, Anuka JA (2016) The effect of methanol rhizome extract of Nymphaea lotus Linn. (Nymphaeaceae) in animal models of diarrhoea. J Ethnopharmacol 190:13-21. https://doi.org/10.1016/j.jep.2016.05.036

Bertaccini G, Molina E, Zappia L, Zseli J (1979) Histamine receptors in the guinea pig ileum. Arch Pharmacol 309:65-68. https://doi.org/10.1007/ 978-1-4471-4483-0_33

Brijesh S, Daswani P, Tetali P, Antia N, Birdi T (2009) Studies on the antidiarrhoeal activity of Aegle marmelos unripe fruit: validating its traditional usage. BMC Complement Altern Med 9(47):1-12. https://doi.org/10.1186/ 1472-6882-9-47

Calzada F, Arista R, Pérez H (2010) Effect of plants used in Mexico to treat gastrointestinal disorders on charcoal-gum acacia-induced hyperperistalsis in rats. J Ethnopharmacol 128(1):49-51. https://doi.org/10.1016/j. jep.2009.12.022

Chaddha V, Kushwah AS, Shrivastava V (2013) An importance of herbal drugs as anti diarrheal: a review. Int J Res Appl Nat Soc Sci 1(7):25-28

Dahiru D, Sini JM, John-Africa L (2006) Antidiarrhoeal activity of Ziziphus mauritiana root extract in rodents. Afr J Biotechnol 5(10):941-945. https://doi. org/10.4314/ajb.v5i10.42946

De La Fuente R, Namkung W, Mills A, Verkman AS (2008) Small-molecule screen identifies inhibitors of a human intestinal calcium-activated chloride channel. Mol Pharmacol 73(3):758-768. https://doi.org/10. 1124/mol.107.043208

De Oliveira Formiga R, De Fátima Formiga Melo Diniz M, Marinho AF, Tavares JF, Batista LM, Quirino ZGM (2017) Maytenus erythroxylon Reissek (Celastraceae) ethanol extract presents antidiarrheal activity via antimotility and antisecretory mechanisms. World J Gastroenterol 23(24):4381-4389. https://doi.org/10.3748/wjg.v23.i24.4381

Di Carlo G, Autore G, Izzo AA, Maiolino P, Mascolo N, Viola P, Diurno MV, Capasso F (1993) Inhibition of intestinal motility and secretion by flavonoids in mice and rats: structure activity relationships. J Pharm Pharmacol 45(12):1054-1059. https://doi.org/10.1111/j.2042-7158. 1993.tb07180.x

Dosso K, N'guessan BB, Bidie AP, Gnangoran BN, Méité S, N'guessan D, Yapo AP, Ehilé EE (2012) Antidiarrhoeal activity of an ethanol extract of the stem bark of Piliostigma reticulatum (Caesalpiniaceae) in rats. Afr J Tradit Complement Altern Med 9(2):242-249. https://doi.org/10.4314/ ajtcam.v9i2.9

Emudainohwo JOT, Moke GE, Ejebe DE, Earnest O (2015) An investigation into the anti-diarrhoeal effects of aqueous and ethanol stem bark extracts of Alchornea cordifolia in Wistar rats. J Pharmacogn Phytochem 4(1):183-187

Ezeja IM, Ezeigbo II, Madubuike KG, Udeh NE, Ukweni IA, Akomas SC, Ifenkwe DC (2012) Antidiarrheal activity of Pterocarpus erinaceus methanol leaf extract in experimentally-induced diarrhea. Asian Pac J Trop Med 5(2):147-150. https://doi.org/10.1016/S1995-7645(12)60014-5

Holzer P (2009) Opioid receptors in the gastrointestinal tract. Regul Pept 155(1-3):11-17. https://doi.org/10.1016/j.regpep.2009.03.012

Hughes S, Higgs NB, Turnberg LA (1982) Antidiarrhoeal activity of loperamide: studies of its influence on ion transport across rabbit ileal mucosa in vitro. Gut 23(11):974-979. https://doi.org/10.1136/gut.23.11.974

Hyacinth AA, Nwocha UC (2011) Antifertility activity of aqueous ethanolic extract of Hymenocardia acida stem bark in female rats. Iran J Reprod Med 5(8):1280-1283 
Ibrahim H, Sani FS, Danladi BH, Ahmadu AA (2007a) Phytochemical and antisickling studies of the leaves of Hymenocardia acida Tul (Euphorbiaceae). Pak J Biol Sci 10(5):788-791

Ibrahim JA, Muazzam I, Jegede IA, Kunle OF, Okogun JI (2007b) Ethno-medicinal plants and methods used by Gwandara tribe of Sabo Wuse in Niger State, Nigeria, to treat mental illness. Afr J Tradit Complement Altern Med 4(2):211-218. https://doi.org/10.4314/ajtcam.v4i2.31210

Igoli OJ, Alexander GI (2008) Friedelanone and other triterpenoids from Hymenocardia acida. Int J Phys Sci 3(6):156-158

Khan A, ur Rehman N, AlKharfy KM, Gilani AH (2011) Antidiarrheal and antispasmodic activities of Salvia officinalis are mediated through activation of K+ channels. Bangladesh J Pharmacol 6(2):111-116. https://doi.org/10, 3329/bjp.v6i2.9156

Knecht H, Neulinger SC, Heinsen FA, Knecht C, Schilhabel A, Schmitz RA, Zimmermann A, Dos Santos VM, Ferrer M, Rosenstiel PC, Schreiber S, Friedrichs AK, Ott SJ (2014) Effects of b-lactam antibiotics and fluoroquinolones on human gut microbiota in relation to Clostridium difficile associated diarrhea. PLoS ONE 9(2):1-8. https://doi.org/10.1371/journal. pone.0089417

Kola-Mustapha AT, Ghazali YO, Ayotunde HT, Atunwa SA, Usman SO (2019) Evaluation of the antidiarrheal activity of the leaf extract of Parquetina nigrescens and formulation into oral suspensions. J Exp Pharmacol 11:65-72. https://doi.org/10.2147/JEP.S214417

Lutterodt GD (1992) Inhibition of microlax-induced experimental diarrhoea with narcotic-like extracts of Psidium guajava leaf in rats. J Ethnopharmacol 37(2):151-157. https://doi.org/10.1016/0378-8741(92)90073-Z

Mahesh GS, Paras P, Manish P, Samresh PR, Asish NP (2010) antidiarrheal activity of methanolic extract of Moringa oleifera Lam roots in experimental animal models. Int J Pharmaceut Res 2(2):35-39

Martins J, Brijesh S (2018) Phytochemistry and pharmacology of anti-depressant medicinal plants: a review. Biomed Pharmacother 104:343-365. https://doi.org/10.1016/j.biopha.2018.05.044

Mekonnen B, Asrie AB, Wubneh ZB (2018) Antidiarrheal activity of 80\% methanolic leaf extract of Justicia schimperiana. Evid Based Complement Altern Med 2018:3037120. https://doi.org/10.1155/2018/3037120

Monirul Islam M, Sharmin Pia R, Sifath-E-Jahan K, Chowdhury J, Akter F, Parvin $\mathrm{N}$, Akter S (2013) Antidiarrheal activity of Dillenia indica bark extract. Int J Pharm Sci Res 4(2):682-688

Monteiro FS, Carvalho AFS, Marques EC, Ribeiro RM, Borges ACR, Borges MOR (2018) Antidiarrhoeal and antispasmodic activity of leaves of Syzygium cumini L.(Myrtaceae) mediated through calcium channel blockage. Afr J Pharm Pharmacol 12(1):11-18

Mukherjee PK, Harwansh RK, Bahadur S, Banerjee S, Kar A, Chanda J, Biswas S, Ahmmed SM, Katiyar CK (2017) Development of ayurveda-tradition to trend. J Ethnopharmacol 197:10-24. https://doi.org/10.1016/j.jep.2016. 09.024

Nduikui J, Murithi B, Muwonge H, Sembajwe L, Kateregga J (2013) Antidiarrheal activity of ethanolic fruit extract of Psidium guajava (Guava) in castor oil induced diarrhea in albino rats. Natl J Physiol Pharm Pharmacol 3(2):191. https://doi.org/10.5455/njppp.2013.3.100620131

Njume C, Goduka NI (2012) Treatment of diarrhoea in rural African communities: an overview of measures to maximize the medicinal potentials of indigenous plants. Int J Environ Res Public Health 9(11):3911-3933. https://doi.org/10.3390/ijerph9113911

Obidike IC, Idris-Usman MS, John-Africa LB, Salawu OA (2011) An evaluation of acute and subchronic toxicological effects of Hymenocardia acida leaf extract in adult Wistar rats. J Pharmacol Toxicol 6(4):400-408

Ogbonnia SO, Olayemi SO, Anyika EN, Enwuru VN, Poluyi OO (2009) Evaluation of acute toxicity in mice and subchronic toxicity of hydroethanolic extract of Parinari curatellifolia Planch (Chrysobalanaceae) seeds in rats. Afr J Biotechnol 8(9):1800-1806. https://doi.org/10.5897/AJB2009. 000-9257

Okpara JO, Ambali FS, Ayo JO, Ayo YO, Suleiman MM (2017) Antidiarrhoeal and antimotility activity of the maize silk (Stigmas maydis) aqeous extract. Int J Sci Appl Res 2(1):1-4
Organization for Economic Cooperation and Development (OECD) (2001) Guidelines for the testing of chemicals: Health effect Test No. 423. Acute Oral Toxicity-Acute Toxic Class Method, Paris, France

Pandey P, Mehta A, Hajra S (2012) Antidiarrhoeal activity of ethanolic extracts of Ruta graveolens leaves and stem. Asian J Pharm Clin Res 5(4):65-68

Paredes JD, Sosa Á, Fusco M, Teves MR, Wendel GH, Pelzer LE (2016) Antidiarrhoeal activity of Aristolochia argentina Gris. (Aristolochiaceae) in rodents. J Appl Pharmaceut Sci 6(2):146-152. https://doi.org/10.7324/JAPS.2016. 60223

Riaz MB, Khan AU, Qazi NG (2020) Pharmacological and computational evaluation of Sapodilla and its constituents for therapeutic potential in hyperactive gastrointestinal disorders. Iran J Basic Med Sci 23(2):224-235. https:// doi.org/10.22038/JBBMS.2019.35595.8488

Robert A, Nezamis JE, Lancaster C, Hanchar A, Klepper MS (1975) Enteropooling assay: a test for diarrhoea produced by prostaglandins. J Chem Inf Model 2(5):809-828

Sahoo HB, Sagar R, Kumar A, Bhaiji A, Bhattamishra SK (2016) Antidiarrhoeal investigation of Apium leptophyllum (Pers) by modulation of $\mathrm{Na}^{+} \mathrm{K}^{+}$ATPase, nitrous oxide and intestinal transit in rats. Biomed J 39(6):376-381. https://doi.org/10.1016/j.bj.2016.11.003

Saikia B, Barua CC, Haloi P, Patowary P (2017) Anticholinergic, antihistaminic, and antiserotonergic activity of $n$-hexane extract of Zanthoxylum alatum seeds on isolated tissue preparations: an ex vivo study. Indian J Pharmacol 49(1):42-48. https://doi.org/10.4103/0253-7613.201025

Sanders KM (2008) Regulation of smooth muscle excitation and contraction. Neurogastroenterol Motil 20(1):39-53. https://doi.org/10.1111/j.13652982.2008.01108.x

Shoba FG, Molly T (2014) Evaluation of anti-diarrhoeal effect of four medicinal plants on castor oil-induced gastrointestinal motility in mice. Adv Appl Sci Res 5(4):153-156

Sofidiya MO, Odukoya OA, Adedapo AA, Mbagwu HOC, Afolayan AJ, Familoni OB (2010) Investigation of the anti-inflammatory and antinociceptive activities of Hymenocardia acida Tul. (Hymenocardiaceae). Afr J Biotechnol 9(49):8454-8459. https://doi.org/10.4314/ajb.v9i49

Sofowora A (1993) Medicinal plants and traditional medicine in Africa, 2nd edn. Spectrum Books Ltd., New Delhi

Starks CM, Williams RB, Norman VL, Rice SM, O'Neil-Johnson M, Lawrence JA, Eldridge GR (2014) Antibacterial chromene and chromane stilbenoids from Hymenocardia acida. Phytochemistry 98:216-222. https://doi.org/10 1016/j.phytochem.2013.11.012

Tadesse E, Engidawork E, Nedi T, Mengistu G (2017) Evaluation of the antidiarrheal activity of the aqueous stem extract of Lantana camara Linn (Verbenaceae) in mice. BMC Complement Altern Med 17(1):1-8. https:// doi.org/10.1186/s12906-017-1696-1

Tor-Anyin TA, Shimbe RY, Anyam JV (2013) Phytochemical and medicinal activities of Hymenocardia acida Tul. (Euphorbiaceae): a review. J Nat Prod Plant Resour 3(4):11-16

Tuenter E, Exarchou V, Baldé A, Cos P, Maes L, Apers S, Pieters L (2016) Cyclopeptide alkaloids from Hymenocardia acida. J Nat Prod 79(7):1746-1751. https://doi.org/10.1021/acs.jnatprod.6b00131

Ukwe CV (2004) Evaluation of the anti-ulcer activity of aqueous stem-bark extract of Hymenocardia acida (Euphorbiaceae). Niger J Pharm Res 3(1):86-90. https://doi.org/10.1080/09251619708951282

Umer S, Tekewe A, Kebede N (2013) Antidiarrhoeal and antimicrobial activity of Calpurnia aurea leaf extract. BMC Complement Altern Med 13:1-5. https://doi.org/10.1186/1472-6882-13-21

Ventura-Martinez R, Angeles-Lopez GE, Gonzalez-Trujano ME, Carrasco OF, Deciga-Campos M (2020) Study of antispasmodic and antidiarrheal activities of Tagetes lucida (Mexican Tarragon) in experimental models and its mechanism of action. Evid Based Complement Altern Med. https://doi.org/10.1155/2020/7140642

Vongtau HO, Abbah J, Mosugu O, Chindo BA, Ngazal IE, Salawu AO, Kwanashie HO, Gamaniel KS (2004) Antinociceptive profile of the methanolic extract of Neorautanenia mitis root in rats and mice. J Ethnopharmacol 92(2-3):317-324. https://doi.org/10.1016/j.jep.2004.03.014 
Wansi SL, Ruphin C, Deumeni M, Laure S, Kamani P, Sama LF, Mireille L, Tchoumi T, Kuiate JR, Fonkem Sama L (2017) Antidiarrhoeal activity of aqueous and methanolic Alchornea laxiflora (Euphorbiaceae) leaves extracts in rats. J Med Plants Stud 5(1):205-211

Whyte LA, Jenkins HR (2012) Pathophysiology of diarrhoea. Paediatr Child Health 22(10):443-447. https://doi.org/10.1016/j.paed.2012.05.006

Yakubu MT, Nurudeen QO, Salimon SS, Yakubu MO, Jimoh RO, Nafiu MO, Akanji MA, Oladiji AT, Williams FE (2015) Antidiarrhoeal activity of Musa paradisiaca sap in wistar rats. Evid Based Complement Altern Med 2015(683726):1-9. https://doi.org/10.1155/2015/683726

Yilgwan CS, Okolo SN (2012) Prevalence of diarrhea disease and risk factors in Jos University Teaching Hospital, Nigeria. Ann Afr Med 11(4):217-221. https://doi.org/10.4103/1596-3519.102852
Yuet Ping K, Darah I, Chen Y, Sreeramanan S, Sasidharan S (2013) Acute and subchronic toxicity study of Euphorbia hirta L. methanol extract in rats. BioMed Res Int 2013(182064):1-4. https://doi.org/10.1155/2013/182064 Zahoor M, Yousaf Z, Aqsa T, Haroon M, Saleh N, Aftab A, Javed S, Qadeer M, Ramazan H (2017) An ethnopharmacological evaluation of Navapind and Shahpur Virkanin district Sheikupura, Pakistan for their herbal medicines. J Ethnobiol Ethnomed 13(1):1-26. https://doi.org/10.1186/ s13002-017-0151-1

\section{Publisher's Note}

Springer Nature remains neutral with regard to jurisdictional claims in published maps and institutional affiliations.

\section{Submit your manuscript to a SpringerOpen ${ }^{\circ}$ journal and benefit from:}

- Convenient online submission

- Rigorous peer review

- Open access: articles freely available online

- High visibility within the field

- Retaining the copyright to your article

Submit your next manuscript at $\boldsymbol{\nabla}$ springeropen.com 